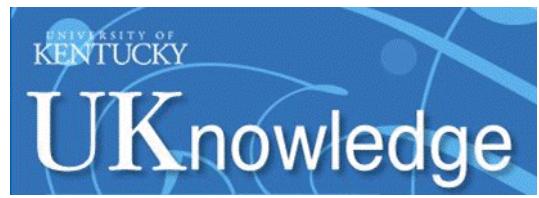

University of Kentucky UKnowledge

3-2005

\title{
Aluminium Content of Some Foods and Food Products in the USA, with Aluminium Food Additives
}

Salim M. Saiyed

University of Kentucky

Robert A. Yokel

University of Kentucky, ryokel@email.uky.edu

Right click to open a feedback form in a new tab to let us know how this document benefits you. Follow this and additional works at: https://uknowledge.uky.edu/ps_facpub

Part of the Pharmacy and Pharmaceutical Sciences Commons 


\section{Aluminium Content of Some Foods and Food Products in the USA, with Aluminium Food Additives}

Digital Object Identifier (DOI)

https://doi.org/10.1080/02652030500073584

Notes/Citation Information

Published in Food Additives \& Contaminants, v. 22, issue 3.

This is an Accepted Manuscript version of the following article, accepted for publication in Food Additives \& Contaminants.

Saiyed, S. M., \& Yokel, R. A. (2005). Aluminium content of some foods and food products in the USA, with aluminium food additives. Food Additives and Contaminants, 22(3), 234-244. https://doi.org/10.1080/ 02652030500073584

It is deposited under the terms of the Creative Commons Attribution-NonCommercial-NoDerivatives License (https://creativecommons.org/licenses/by-nc-nd/4.0/), which permits non-commercial re-use, distribution, and reproduction in any medium, provided the original work is properly cited, and is not altered, transformed, or built upon in any way. 


\title{
Aluminium content of some foods and food products in the USA, with aluminium food additives
}

\author{
Salim M. Saiyed ${ }^{1}$ and Robert A. Yokel ${ }^{1,2}$ \\ ${ }^{1}$ College of Pharmacy and ${ }^{2}$ Graduate Center for Toxicology, University of Kentucky \\ Medical Center, Lexington, Kentucky, USA 40536-0082
}

Corresponding author:

Robert A. Yokel, Ph.D.

511C Pharmacy Building

725 Rose Street

University of Kentucky Medical Center

Lexington, KY40536-0082

phone: $859-257-4855$

fax: 859-323-6886

E-mail: ryokel@email.uky.edu 


\begin{abstract}
The primary objective was to determine the aluminium (Al) content of selected foods and food products in the USA which contain Al as an approved food additive. Intake of Al from the labeled serving size of each food product was calculated. The samples were acid or base digested and analyzed for Al using electrothermal atomic absorption spectrometry. Quality control (QC) samples, with matrices matching the samples, were generated and used to verify the $\mathrm{Al}$ determinations. Food product $\mathrm{Al}$ content ranged from $<1$ to $27,000 \mathrm{mg} \mathrm{kg}^{-1}$. Cheese in a serving of frozen pizzas had up to $14 \mathrm{mg}$ of $\mathrm{Al}$, from basic sodium aluminium phosphate; whereas the same amount of cheese in a ready-to-eat restaurant pizza provided 0.03-0.09 mg. Many single serving packets of non-dairy creamer had $\sim 50$ to $600 \mathrm{mg} \mathrm{Al} \mathrm{kg}{ }^{-1}$ as sodium aluminosilicate, providing up to $1.5 \mathrm{mg} \mathrm{Al}$ per serving. Many single serving packets of salt also had sodium aluminosilicate as an additive, but the $\mathrm{Al}$ content was less than in single-serving non-dairy creamer packets. Acidic sodium aluminium phosphate was present in many food products, pancakes and waffles. Baking powder, some pancake/waffle mixes and frozen products, and ready-toeat pancakes provided the most $\mathrm{Al}$ of the foods tested; up to $180 \mathrm{mg} / \mathrm{serving}$. Many products provide a significant amount of Al compared to the typical intake of 3-12 $\mathrm{mg}$ /day reported from dietary Al studies conducted in many countries.
\end{abstract}




\section{Introduction}

Aluminium (Al) is distributed throughout the environment because of its presence as the third most abundant element on earth. Concern about Al toxicity to humans has persisted since the demonstration that it has the potential to be a neurotoxicant (Döllken 1898; Gies 1911; Anon. 1913; WHO 1997; Yokel and Golub 1997; ATSDR 1999). Aluminium can be toxic to bone, bone marrow and the nervous system. There is a proposed relationship between Al in the brain and the occurrence of Alzheimer's disease and other neurodegenerative disorders (Exley 2001). Exposure of humans to Al is mainly from food, water, airborne dust, antiperspirants, immunizations, allergy injections and antacids. Food is the single largest contributor of Al intake for the typical human (Yokel and McNamara 2001). Aluminium is present in food naturally, from its addition as food additives, and through contact with $\mathrm{Al}$ used in food preparation and storage (Pennington 1987). The U.S. Food and Drug Administration (FDA) permits the use of Al salts as generally recognized as safe (GRAS) food additives (21 CFR 182). Canada permits this practice, as described in Part B Foods Division 16 of its Food and Drug Regulations (http://www.hc-sc.gc.ca/food-aliment/friia-raaii/food_drugs-aliments_drogues/actloi/e_index.html). The Canadian Food and Drugs Act regulations are similar to the FDA's. The fifteen member states of the European Union, as well as Norway and Iceland, allow the use of $\mathrm{Al}$ as a food additive (http://europa.eu.int/eurlex/en/consleg/pdf/1995/en_1995L0002_do_001.pdf) (http://193.120.54.7/publications/reports/Legislation_Food_Additives.pdf), as does the United Kingdom (http://www.legislation.hmso.gov.uk/si/si1995/Uksi_19953187_en_5.htm\#sdiv3) and 
Australia and New Zealand

(http://www.foodstandards.gov.au/mediareleasespublications/publications/shoppersguide/f oodadditivesnumeric1680.cfm). However, Poland apparently did not permit Al-based food additives (Starska 1993). Examples of permitted Al additives include basic sodium aluminium phosphate (SALP) (E 554 in the EC) as an emulsifying agent in pasteurized process cheese, cheese food and cheese spread (21 CFR 133); acidic SALP (E 541 in the EC) as a leavening agent in cereal foods and related products (21 CFR 137); and sodium aluminosilicate (SAS) (E 554 in the EC) as an anti-caking agent. There have been many reports of the $\mathrm{Al}$ content of foods and beverages, including a summary of reports from many countries up to the mid-1980s (Pennington 1987), a study in the UK from 1985 to 1993 (UK MAFF 1993) and another in 1997 (Ysart et al. 2000) and a study of foods in Germany from 1988 and 1991 (Müller et al. 1998). These studies identified approved food additives as the primary source of $\mathrm{Al}$ in food.

The annual use of Al-containing food additives in the USA has probably increased over the past several years due to the many recent additions of SALP to foods. In 1982, four million pounds of $\mathrm{Al}$ were used as food additives in the USA (NRC 1984). There are two major companies in the global phosphates industry, Rhodia and Astaris. Rhodia completed an expansion in 1998 to its Nashville plant to increase its SALP capacity by 15\% (1998) and Astaris was investing in capacity additions in 2001 because demand for its SALP exceeded capacity (Challener 2000).

Few investigations have been conducted recently in the USA to determine the Al content of food products that contain $\mathrm{Al}$ as an approved additive. Therefore we conducted a study to document the current levels of $\mathrm{Al}$ in selected foods and food products. The 
primary aim of this study was to determine the $\mathrm{Al}$ content of representative food products available commercially in the USA. To achieve this aim, methods were developed and validated to prepare and analyze $\mathrm{Al}$ in the food and food products. The analysis of $\mathrm{Al}$ is challenging because of its low concentrations in some foods and the potential for contamination during sample preparation and analysis (Vinas et al. 2001). To validate the procedures we developed, QC samples were prepared because reference or certified materials that could be used as QC standards were not available commercially in relevant matrices, e.g., $\mathrm{Al}$ in food products similar to those we tested. Food products selected for study were those containing $\mathrm{Al}$ as well as similar products which did not list $\mathrm{Al}$ as an ingredient. The representative food products studied included pizza cheese, pizza crust, cheese, grains, baked goods, cake mixes, baking powder, pancakes and waffles, non-dairy creamers, salt, and pickle relish. The amount of $\mathrm{Al}$ in a serving of each of these representative food products was calculated and compared to the reported values of typical human daily $\mathrm{Al}$ intake from the diet. 


\section{Material and Methods}

Approximately ninety-five single sample purchases were made locally during 2003-2004, unless otherwise noted, of different food products in selected categories, as shown in the tables. The products purchased are nationally available and house brands which are presumed to be available nationally. They were selected to be representative of products that did, or did not, have added Al, according to the Nutrition Facts label. The purchase locations were varied, but since all the products were national brands or house brands of national chains, it was assumed the products would be the same if purchased elsewhere. Some were known to contain Al from their list of ingredients. Most were prepared for electrothermal atomic absorption spectrometric (ETAAS) analysis of Al, as described (Yokel and Melograna 1983). Many of the samples analyzed were powder-like materials, assumed to be homogeneous. The relish samples were homogenized in a Waring® blender before analyzing the samples. A $35 \mathrm{mg}$ sample of the food product, as purchased, was accurately weighed in a pre-weighed Teflon $®$ screw cap container. All the pizzas studied had cheese. A portion of pizza (averaging $13 \mathrm{gm}$ ) was weighed and the cheese carefully separated from the remaining ingredients and weighed to determine the average weight of the cheese as a percentage of the sample. This process was repeated for 2 or 3 additional replicate samples. Non-cheese samples were digested using one $\mathrm{ml}$ of 70:30 $\mathrm{HNO}_{3}: \mathrm{H}_{2} \mathrm{O}_{2}$ in closed Teflon $®$ containers overnight on a $100{ }^{\circ} \mathrm{C}$ hot plate (temperature determined by thermocouple), followed by acid and liquid evaporation typically at $90{ }^{\circ} \mathrm{C}$ for 5 to 6 hours and then at $135{ }^{\circ} \mathrm{C}$ for 2 to 3 hours. After acid evaporation the sample residue was dissolved by addition of $0.14 \mathrm{ml}$ of $70 \% \mathrm{HNO}_{3}$ in the Teflon $®$ container on a hot plate at $\sim 100{ }^{\circ} \mathrm{C}$ overnight. When necessary to dissolve the 
residue, an additional $0.21 \mathrm{ml}$ of $70 \% \mathrm{HNO}_{3}$ was added. The resulting solution was then diluted with $\mathrm{H}_{2} \mathrm{O}$ and $\mathrm{Mg}$ addition to produce a final matrix of $0.2 \% \mathrm{HNO}_{3}$ and $2.5 \mathrm{mM}$ Mg. Samples were further diluted in this matrix, when necessary, to generate an $\mathrm{Al}$ concentration within the standard curves used for ETAAS, using a Perkin Elmer 4100 ZL spectrophotometer. Standards were prepared from an atomic absorption standard solution (Aldrich Chemical Company, Milwaukee, WI, USA) in the same matrix. Samples containing SAS required addition of $48 \% \mathrm{HF}$ to solubilize the Al.

Another method was developed for cheese samples because they did not completely dissolve in 70:30 $\mathrm{HNO}_{3}: \mathrm{H}_{2} \mathrm{O}_{2}$ owing to their high fat content, potentially resulting in poor $\mathrm{Al}$ analysis. Furthermore, digestion of cheese using $\mathrm{HNO}_{3}$ has been stated to be hazardous due to its high fat content by (Delves et al. 1989) who developed a method to remove the lipid fraction by solvent extraction with petroleum ether and then back extraction of the $\mathrm{Al}$ into $0.1 \mathrm{M} \mathrm{HNO}_{3}$. We tried to apply this method with back extraction into $0.1 \mathrm{M} \mathrm{HNO}_{3}$ and alternatively $5 \mathrm{M} \mathrm{KOH}$. This did not work because the high volatility of petroleum ether made quantification of $\mathrm{Al}$ in it difficult using ETAAS. Therefore, we could not verify recovery of Al, by back extraction, from lipid. Recovery of Al from the organic phase was deemed essential because full recovery was not obtained from the aqueous phase. We observed that the $\mathrm{KOH}$ dissolved the cheese.

Therefore we developed a new method to digest cheese to create homogenous samples for $\mathrm{Al}$ analysis. A sample of $\sim 30$ to $35 \mathrm{mg}$ of cheese was digested in $1 \mathrm{ml}$ of $1 \%$ $\mathrm{KOH}$ overnight on a hot plate at $\sim 100{ }^{\circ} \mathrm{C}$. This resulted in a solution with some lipid particles floating on the surface. This was sonicated using a Fischer Scientific Sonic Dismembrator Model 500 for 20 seconds, with a 5 second pause after the first 10 
seconds, at $22 \%$ amplitude, producing a cloudy solution with no floating particles. The samples were then diluted immediately, into a final matrix of $0.001 \% \mathrm{KOH} / 2.5 \mathrm{mM} \mathrm{Mg}$ and analyzed for Al using by ETAAS. The $\mathrm{pH}$ of $0.001 \% \mathrm{KOH}$ is $\sim 7.5$, acceptable for injection into the graphite tube for ETAAS. Standards were prepared from an Al atomic absorption standard, as noted above, in the same matrix.

Blanks were included with each batch of samples prepared for $\mathrm{Al}$ analysis to estimate the background $\mathrm{Al}$ contamination of the procedure. Blanks were Teflon $®$ containers that did not contain sample but received the same treatments as the samples.

An Al recovery study of this method of cheese digestion was conducted by adding $37.9 \mathrm{mg} \mathrm{Al} \mathrm{kg}{ }^{-1}$ to $~ 35 \mathrm{mg}$ samples of Swiss, American and cheddar cheese and processing the samples for $\mathrm{Al}$ analysis.

The recommended conditions for Al analysis by ETAAS were modified, as shown below, and utilized for analysis of all samples. An inert gas (argon) flow rate of 250 $\mathrm{ml} / \mathrm{min}$ was used. Twenty $\mu \mathrm{l}$ injections of samples and standards were made.

\begin{tabular}{lccc} 
Step & Temperature $\left({ }^{\circ} \mathrm{C}\right)$ & Ramp time (s) & Hold time (s) \\
\hline 1 (Dry) & 110 & 5 & 20 \\
2 (Dry) & 130 & 5 & 45 \\
3 (Char) & 1600 & 10 & 20 \\
4 (Atomization) & 2400 & 0 & 3 \\
5 (Clean) & 2500 & 1 & 1
\end{tabular}


Different QC samples were prepared for each type of food analyzed. All food samples were initially analyzed at least once to ascertain their approximate $\mathrm{Al}$ concentration. Quality control samples were then created by addition of sufficient Al to a food containing very little $\mathrm{Al}$ to bring the total $\mathrm{Al}$ into the range of typical samples of that type of food. For example, Al was added to sample D25, which had $\sim 11 \mathrm{mg} \mathrm{Al} \mathrm{kg}^{-1}$ (table 4) to bring the $\mathrm{Al}$ concentration to $\sim 580 \mathrm{mg} \mathrm{kg}^{-1}$ (table 8), and into the range of $\mathrm{Al}$ concentrations seen in pancake, hot cake and waffle products containing considerable Al (table 4). To create the QC samples $\mathrm{AlK}_{2} \mathrm{SO}_{4}$ or Kasal® $(70 \%$ basic SALP and $30 \%$ dibasic sodium phosphate) was added to the solid samples and an atomic absorption standard solution of $\mathrm{Al}$ was added to the homogenized semi-liquid sample. The added $\mathrm{Al}$ was introduced into a small amount of the food. This was diluted with further addition of food to try to achieve uniform $\mathrm{Al}$ distribution throughout the QC sample. Cheese QC samples were prepared by adding Kasal® to a 9:1 cheese:water mixture and microwaving it for 13 and 5 second cycles, separated by 15 seconds during which time the mixture was stirred. Quality control samples containing the solid food products were produced by adding $\mathrm{Al}$ and mixing them well for approximately 20 minutes in a Waring® blender. A sample of relish was homogenized in the blender, $\mathrm{Al}$ was added, and the mixture vortexed for 10 to 15 minutes to make that $\mathrm{QC}$ sample. Five replicate aliquots of each QC were prepared for $\mathrm{Al}$ analysis, using the procedures described above for samples, and analyzed. The QC samples were then included with at least one batch of every sample analyzed to validate the sample preparation and analysis procedure. Results were accepted when the $\mathrm{Al}$ concentration of the QC samples was within $10 \%$ of the mean of the five replicate aliquots. The cheese QC was included with analysis of samples 
containing pizza cheese and other cheese products. Similarly non-dairy creamer, salt, baking mix and relish QCs were included with their respective samples. Cake mix QC was included with the cake mix samples and hot cocoa mix. Waffle QC was included with pancake, hot cake and waffle samples.

The Al concentration in samples was determined in three or four independently conducted analyses of a single purchase of the food product. The one exception is B05 in table 2, for which 2 separate purchases were made from different locations. The Al concentration results are reported as the mean \pm S.D. of three replicate observations, and for samples analyzed four times, as indicated by ${ }^{*}$ in the tables. The results are based on the weight of the product as purchased. 


\section{Results}

The recovery of Al from the Swiss, American and cheddar cheeses was within $10 \%$ of complete, suggesting the new method to digest cheese was acceptable. The method was then used to digest all cheese samples.

The relative standard deviation of the five replicates of each QC sample was $<$ $10 \%$, indicating that these samples were sufficiently homogenous and the analysis consistent enough to use these as QC samples to validate the methods of samples subsequently analyzed.

The results of $\mathrm{Al}$ determination in the food products are shown in tables 1 to 7 . The Al contributing ingredients, according to the product's Nutrition Facts label, were SALP or SAS. The Al concentration determined in the samples was converted to Al in a labeled recommended serving to enable comparisons among products and to reported daily $\mathrm{Al}$ intakes.

The labeled recommended serving size of the frozen pizza contained an average of $14 \mathrm{~g}$ of $\mathrm{Al}$ in the cheese (table 1). The $\mathrm{Al}$ in the cheese of a serving of ready-to-eat restaurant pizza and other cheese products which do not mention use of $\mathrm{Al}$ as an additive was $\sim 0.04$ to $0.7 \mathrm{mg}$ (tables $2 \& 3$ ). The results in table 1 show that $\mathrm{Al}$ is an ingredient in many frozen pizzas, and when present provides a considerable amount of Al. Processed cheese slices do not commonly contain added $\mathrm{Al}$. When $\mathrm{Al}$ is present, less is present than in most frozen pizza cheeses (tables $1 \& 3$ ). In contrast to frozen pizzas, the cheese in ready to eat (restaurant, carry-out, take-away) pizzas (table 2) had very little Al, suggesting Al had not been added. As the serving sizes of ready-to-eat pizzas are not provided with the product, we used the average amount of cheese and crust of frozen 
pizzas to estimate the serving size of cheese in ready-to-eat pizzas (table 2) to enable calculation of $\mathrm{Al}$ consumption from a typical serving. One pizza crust contained a large amount of $\mathrm{Al}$, whereas $\mathrm{Al}$ did not appear to be an additive in others (tables $1 \& 2$ ).

\section{(tables $1,2 \& 3$ about here)}

Food products such as flour and cake mixes and foods such as cinnamon rolls, pancakes and waffles had variable Al content (table 4). Some products had little Al whereas some similar products had considerable amounts. The baking powders tested contained considerable $\mathrm{Al}$ (table 4).

\section{(table 4 about here)}

It appears that SAS is added to most non-dairy creamer products as an anti-caking agent (table 5). One recommended serving size provides 0.1 to $1.5 \mathrm{mg}$ Al. SAS is also routinely added to single use packets of salt (table 6). In contrast, only some salt sold in multi-use containers had added $\mathrm{Al}$, according to the list of ingredients and the results (table 6). Al intake from one serving of Al-containing salt was $\sim 0.1$ to $0.2 \mathrm{mg}$ whereas the samples without added Al provide negligible Al. Pickle relish often contains Al (table 7).

(tables 5, 6 and 7 about here)

The QC samples prepared by adding a known amount of Al to samples that contained little $\mathrm{Al}$ are shown in table 8 . The brand codes in table 8 correspond to the 
same brands in the previous tables, which report the initial Al concentration of these food products. 


\section{Discussion}

There are many reports of the $\mathrm{Al}$ content of various components of the human diet. The more complete compilations include (Pennington 1987; Schenk et al. 1989; UK MAFF 1993; Müller et al. 1998; ATSDR 1999). There are numerous reports of Al in milk and infant formulae. For example, the Al concentrations in cow- and soy-milk-based infant formula in the UK ranged from 0.03 to 0.2 and 0.53 to $1.34 \mathrm{mg} \mathrm{L}^{-1}$, respectively (Baxter et al. 1990; Baxter et al. 1991). The Al concentrations in 44 brands of milk powders and simulated milk powders in Singapore were generally $<1 \mathrm{mg}$, although some ranged up to $15 \mathrm{mg} \mathrm{kg}^{-1}$ powder in a soy formula (Bloodworth et al. 1991). In 282 cans of infant formulae and evaporated milks sold in Canada, evaporated milk and milk-based formulae generally had lower $\mathrm{Al}$ concentrations, 0.022 to 0.34 and 0.01 to $2.49 \mathrm{mg} \mathrm{kg}^{-1}$, respectively, than soy-based formulae (0.40 to $\left.19 \mathrm{mg} \mathrm{kg}^{-1}\right)$ (Dabeka and McKenzie 1990). Soy-based formulae had the highest Al concentration among the infant formulae tested recently in Spain, 0.313 to 3.48 , vs. 0.068 to $2.72 \mathrm{mg} \mathrm{L}^{-1}$ for other types of formulae (Navarro-Blasco and Alvarez-Galindo 2003). Soy, cow, and breast milk were found to have quite low Al concentrations, 0.005 to $0.285,0.004$ to 0.033 and 0.003 to $0.079 \mathrm{mg} \mathrm{L}^{-1}$, respectively (Baxter et al. 1991). Therefore, infants consuming soy-based formulae receive much more $\mathrm{Al}$ than those consuming milk-based formulae.

Tea contributes a variable percentage of Al to daily intake. The many reports of the $\mathrm{Al}$ concentration in brewed tea suggest the average is $\sim 3$ to $4 \mathrm{mg} \mathrm{L}^{-1} ; 10$-fold or more higher than in coffee (Pennington 1987; Pennington and Jones 1989; Schenk et al. 1989; Sherlock 1989; Baxter et al. 1990; Müller et al. 1998; Sepe et al. 2001). Soft drinks and fruit juices generally contain $<1 \mathrm{mg} \mathrm{Al}^{-1}$ (Pennington 1987; Pennington and Jones 
1989; Baxter et al. 1990; Müller et al. 1998; Sepe et al. 2001). In countries where Al from other sources is relatively small and tea consumption relatively large, as in the UK, tea has been estimated to contribute $\sim 50 \%$ of the total daily $\mathrm{Al}$ intake (UK MAFF 1993).

There are many studies reporting the $\mathrm{Al}$ content of unprocessed and processed foods (Greger 1985; Pennington 1987; Sullivan et al., 1987; Sherlock 1989; Müller et al., 1998). However, there are no recent studies focusing on processed food products in the USA. This study determined the Al concentration in many food and food products that typically contain $\mathrm{Al}$ as a food additive. The results represent the current concentration of $\mathrm{Al}$ in many USA food products; both those containing $\mathrm{Al}$ as a food additive and similar products that do not declare this. The Al concentrations reported in this study are the sum of those inherently present, contributed by food additives and that introduced by processing and storage because the methods used do not distinguish among these sources. Similarly, the addition of ingredients to mixes, such as cake or pancake mixes, could increase the $\mathrm{Al}$ content due to the additions or the processing and storage of the final food product.

Frozen pizza that listed SALP as an additive generally had $\sim 200$ to $750 \mathrm{mg} \mathrm{Al} \mathrm{kg}^{-1}$ cheese (table 1). The cheese from frozen pizza products that did not list $\mathrm{Al}$ as an additive and ready-to-eat pizza had only a few $\mathrm{mg} \mathrm{Al} \mathrm{kg}{ }^{-1}$, similar to a natural cheese (tables 1,2 \& 3). These results are similar to previous reports from several countries of a few $m g \mathrm{Al} \mathrm{kg}^{-1}$ in natural cheese (Pennington 1987) and from the USA (Greger 1985; Schenk et al. 1989), the UK (Delves et al. 1989), Italy (Favretto 1990), India (Rao and Rao 1993), and Germany (Müller et al. 1998). Our findings are also similar to the several hundred up to $750 \mathrm{mg} \mathrm{Al} \mathrm{kg}{ }^{-1}$ in processed cheese in the United States (Gormican 1970; Greger 1985; 
Pennington and Schoen 1995). Thus the $\mathrm{Al}$ content of natural cheese and processed cheese containing added $\mathrm{Al}$ has been reasonably constant for a few decades.

This is the first report to compare the $\mathrm{Al}$ concentration in frozen prepared and ready-to-eat pizza products. The crust (grain product/bread) of frozen pizza that did not list $\mathrm{Al}$ as a food additive and in ready-to-eat pizza contained $\sim 12 \mathrm{mg} \mathrm{Al} \mathrm{kg}^{-1}$ (tables 1 and 2), whereas a frozen pizza listing $\mathrm{Al}$ as an additive (SALP) in the crust had $\sim 200 \mathrm{mg}$ $\mathrm{Al} \mathrm{kg}{ }^{-1}$ (table 1). An extensive review of the literature failed to reveal any previous reports of the $\mathrm{Al}$ concentration in pizza crust. The high concentration of $\mathrm{Al}$ in the crust of the pizza containing $\mathrm{Al}$ as an additive is consistent with baked goods representing the largest source of Al in the typical diet (Pennington 1987).

The $\mathrm{Al}$ concentration in some foods (baked goods) that did not list $\mathrm{Al}$ as an additive was much lower than products that listed, and many products that did not list, $\mathrm{Al}$ as an additive (table 4). It appears that $\mathrm{Al}$ is an additive in some products which do not declare this in the ingredient list. Our observations are consistent with many previous reports showing considerable amounts of added $\mathrm{Al}$ in grain-based foods, particularly those containing self-rising flour (Pennington 1987; Jorhem and Haegglund 1992; Müller et al. 1998; Ysart et al. 2000). The very high $\mathrm{Al}$ concentration in baking powder is also consistent with previous reports of 20,000 to 34,000 mg Al kg-1 (Holak 1970, 1972; Rajwanshi et al. 1997). However, there are reports of baking powders containing much lower Al concentrations ( 0 to $24 \mathrm{mg} \mathrm{kg}^{-1}$ ) (Holak 1970, 1972; Schenk et al. 1989; UK MAFF 1993), suggesting $\mathrm{Al}$ is not essential in these products. We found considerable $\mathrm{Al}$ in many pancake and waffle mixes, frozen and ready to eat products; up to 1200, 600 and $1200 \mathrm{mg} \mathrm{kg}^{-1}$, respectively (table 4). Previous reports found 5 to $9 \mathrm{mg} \mathrm{Al} \mathrm{kg}^{-1}$ in pancake 
wheat in Germany (Müller et al. 1998), 11 to $100 \mathrm{mg} \mathrm{Al} \mathrm{kg}^{-1}$ in pancake mixes (Schenk

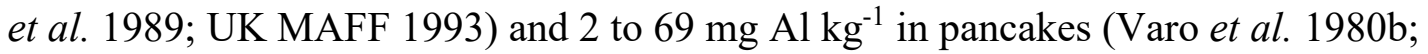
Pennington and Jones 1989; Pennington and Schoen 1995; Dolan and Capar 2002). It appears that the use of $\mathrm{Al}$ in pancake mixes and prepared pancakes in the USA has increased compared to previous surveys.

We found salts that listed SAS as an ingredient contained $\sim 125$ to $200 \mathrm{mg} \mathrm{Al} \mathrm{kg}{ }^{-1}$ and a few salts that did not declare SAS to contain around $3 \mathrm{mg} \mathrm{Al} \mathrm{kg}^{-1}$ (table 6). Salt was previously reported to have $<1$ to $165 \mathrm{mg} \mathrm{Al} \mathrm{kg}^{-1}$ (Varo et al. 1980a; Greger et al. 1985; Schenk et al. 1989; Müller et al. 1998).

Single-use packets of non-dairy creamer had $\sim 110$ to $600 \mathrm{mg} \mathrm{Al} \mathrm{kg}^{-1}$, whereas multiple-serving products contained $\leq 50 \mathrm{mg} \mathrm{Al} \mathrm{kg}{ }^{-1}$. There are a few previous reports of $\mathrm{Al}$ in non-dairy creamers, which contained 25 to $140 \mathrm{mg} \mathrm{Al} \mathrm{kg}^{-1}$ (Pennington and Jones 1989; Schenk et al. 1989), consistent with products currently available in the USA. Our findings of 40 to $73 \mathrm{mg} \mathrm{Al} \mathrm{kg}{ }^{-1}$ in pickle relish are consistent with a single report of 39 mg Al kg-1 in pickles with additives (Greger et al. 1985). The remaining previous reports of the $\mathrm{Al}$ concentration in pickles and a single report of pickle relish reported $\mathrm{Al}$ concentrations of $<1$ to $13 \mathrm{mg} \mathrm{kg}^{-1}$, below the products we tested (Pennington and Jones 1989; Schenk et al. 1989; Gramiccioni et al. 1996; Takeda et al. 1998).

A recent report of $\mathrm{Al}$ in convenience and fast foods noted the increased popularity of these foods (Lopez et al. 2002). Studying beef-, chicken-, fish-, pork- and egg-based foods and sauces in Spain, they found up to $4 \mathrm{mg} \mathrm{Al} /$ food portion for some chicken-based foods. The results of the present study show considerable $\mathrm{Al}$ in many convenience foods. 
Most estimates of $\mathrm{Al}$ intake from 1970 to the present estimated average daily dietary Al intake to be $\sim 6 \mathrm{mg}$ (Sherlock 1989; WHO 1997). For example, daily dietary Al intake in the USA was estimated to average 8 to $11.5 \mathrm{mg}$ for adults and 14 to 16 year old males (Pennington and Schoen 1995). It was estimated the Dutch consume an average of $3.1 \mathrm{mg} \mathrm{Al}$ daily (Ellen et al. 1990), those in the UK $3.4 \mathrm{mg}$ daily (Ysart et al. 2000) and Italians $\sim 5 \mathrm{mg} \mathrm{Al}$ daily (Gramiccioni et al. 1996). However, the individual range of daily $\mathrm{Al}$ intake is great. For example, in a early study, an average daily $\mathrm{Al}$ intake of 24.6 $\mathrm{mg}$ was obtained from a range of 3.8 to $51.6 \mathrm{mg}$ for total diet composites calculated to provide $4200 \mathrm{cal} / \mathrm{day}$ (Zook and Lehman, 1965). Similarly, the estimate of $3.1 \mathrm{mg} \mathrm{Al}$ consumed daily by the Dutch was based on a range of 0.6 to $33 \mathrm{mg}$ for different study subjects (Ellen et al. 1990). Many of the products tested in the present study could easily provide more $\mathrm{Al}$ in one serving than consumed in the average daily diet, and some products are often consumed more than once daily, leading to the potential for even higher daily $\mathrm{Al}$ intake. Examples of products containing considerable $\mathrm{Al}$ are frozen pizza (from the cheese, and sometimes the crust as well) and many foods (baked goods), particularly pancakes. Similar products, for example ready-to-eat pizzas and alternative brands of baked goods, which do not list $\mathrm{Al}$ as an additive, often had much less $\mathrm{Al}$, enabling the consumer to reduce $\mathrm{Al}$ intake through product selection. The absence of $\mathrm{Al}$ in comparable products raises the question whether addition of $\mathrm{Al}$ is necessary in most cases, and suggests that it is not, creating the possibility that the addition of $\mathrm{Al}$ to food products could often be avoided, reducing Al exposure through foods. The data from this study clearly indicate several magnitude higher $\mathrm{Al}$ intake from the food products that have $\mathrm{Al}$ as an additive than those which do not. 
The potential for $\mathrm{Al}$ to contribute to Alzheimer's disease (AD) is controversial. There have been many epidemiological studies designed to assess if there is a link between elevated $\mathrm{Al}$ in drinking water and the development of $\mathrm{AD}$. Some have shown a small but statistically-significant increased odds ratio for dementia in humans who lived in areas with higher drinking water $\mathrm{Al}$ concentrations whereas some studies did not show an association (Rondeau and Commenges 2001). Al consumption from foods is typically $>10$-fold greater than from drinking water. We have found, using ${ }^{26} \mathrm{Al}$-labeled biscuit and cheese, that oral Al bioavailability from these representative foods is $\sim 0.02$ and $0.05 \%$ in the rat (Yokel et al. 2005). This is lower than previous estimates of $0.09 \%$ when Al was added to the diet as Al lactate in fruit juice (Greger and Baier 1983) and estimates of $\sim 0.1 \%$ based on average daily urinary $\mathrm{Al}$ excretion compared to average daily Al intake from food (Powell and Thompson 1993; Priest 1993; Nieboer et al. 1995). The oral bioavailability of $\mathrm{Al}$ from drinking water has been estimated to be $\sim 0.2$ to $0.3 \%$ (Priest et al. 1998; Stauber et al. 1999; Yokel et al. 2001). Therefore food presents more absorbed $\mathrm{Al}$ than drinking water for the typical human.

Al can be mobilized from Al cookware, particularly by acidic and basic foods. For example, cooking tomatoes $(\mathrm{pH} 4.4)$ and rhubarb $(\mathrm{pH}$ 3.4) in an $\mathrm{Al}$ saucepan increased the $\mathrm{Al}$ content of the foods from $\sim 0.16 \mu \mathrm{g} \mathrm{Al} / \mathrm{g}$ wet weight to 21.5 and $42 \mu \mathrm{g}$ $\mathrm{Al} / \mathrm{g}$, whereas cooking them in a Teflon-coated saucepan raised the $\mathrm{Al}$ concentrations to 0.30 and $0.37 \mu \mathrm{g} / \mathrm{g}$ (Fairweather-Tait et al., 1987). Similarly, (Gramiccioni et al., 1996) showed that preparing tomato sauce, French beans, pickles, coffee and tap water in Al cookware increased the $\mathrm{Al}$ content considerably, compared to glassware or stainless steel cookware. Food storage and processing are generally not major contributors to $\mathrm{Al}$ in food 
(Pennington 1987; Sherlock 1989). However, when patients with chronic renal insufficiency who used $\mathrm{Al}$ kitchen utensils for $>1$ year were divided into one group that continued to do so for 3 months and another group that used stainless steel utensils, the latter group showed a significantly greater decrease in serum $\mathrm{Al}$ and daily urine $\mathrm{Al}$ excretion. These results suggest Al kitchen utensils may be a significant Al source for this population (Lin et al. 1997). When foods provide more $\mathrm{Al}$ in the diet than cookware, as is usually the case, one might expect foods that contain considerable Al to have an even greater contribution to the $\mathrm{Al}$ body burden of patients with chronic renal insufficiency than produced by Al kitchen utensils. Contrary to this notion, it has been noted that no public health threat due to Al in food has been detected (Humphreys and Bolger 1997) and that the risk of adverse effects of dietary $\mathrm{Al}$, if there are any, is extremely low (Soni et al. 2001).

A preliminary study of 23 newly-diagnosed AD patients and 23 matched nondemented controls to ascertain the relationship between consumption of foods generally high in $\mathrm{Al}$ during the previous 5 years and dementia showed increased odds ratios for many food categories. However, the results were only significant for the category containing pancakes, waffles, biscuits, muffins, cornbread and corn tortillas. The odds ratio was not elevated for tea consumption, which the authors estimated might contribute $\sim 25 \%$ of the daily Al intake in this population (Rogers and Simon 1999). In another study, oral $\mathrm{Al}$ absorption from an $\mathrm{Al}$ citrate drink was greater in 68 to 76 year old subjects diagnosed with $\mathrm{AD}$ than in age-matched controls, although there was not a significant difference between older patients and age-matched controls (Taylor et al. 1992). These small-scale studies suggest, but certainly do not provide strong evidence 
for, an increased risk of $\mathrm{AD}$ associated with $\mathrm{Al}$ in the diet and its absorption. Given that Al has no health benefits, but has the potential to produce toxicity, at least in people with impaired or absent renal function, some people may wish to avoid $\mathrm{Al}$ when it is practical to do so. 


\section{Acknowledgement}

We thank the Federal Work Study Program for partial support of S. M. Saiyed during the conduct of this study. 


\section{References}

Anon 1998, Rhodia adds SALP. Chemical Week, 160, 73.

Anon., 1913. Culinary and chemical experiments with aluminium cooking vessels. The Lancet, i, 843.

ATSDR (Agency for toxic substances and disease registry) 1999, Toxicological profile for aluminum, Prepared by Research Triangle Institute for ATSDR, Atlanta, GA. Available at: http://www.atsdr.cdc.gov/toxprofiles/tp22.html.

Baxter, M. J., Burrell, J. A., Crews, H., and Massey, R. C., 1991. Aluminium levels in milk and infant formulae. Food Additives and Contaminants, 8, 653-660.

Baxter, M. J., Burrell, J. A., and Massey, R. C., 1990. The aluminium content of infant formula and tea. Food Additives and Contaminants, 7, 101-107.

Bloodworth, B. C., Hock, C. T., and Boon, T. O., 1991. Aluminium content in milk powders by inductively-coupled argon plasma-- optical emission spectrometry. Food Additives and Contaminants, 8, 749-754.

Challener, C. 2000, Food phosphates market restructures. Chemical Market Reporter, 258,5 .

Dabeka, R. W., and McKenzie, A. D., 1990. Aluminium levels in Canadian infant formulate and estimation of aluminium intakes from formulae by infants 0-3 months old. Food Additives and Contaminants, 7, 275-282.

Delves, H. T., Suchak, B., and Fellows, C. S. 1989, The determination of aluminium in foods and biological materials. Aluminium in food and the environment. The proceedings of a symposium organized by the Environment and Food Chemistry Groups of the Industrial Division of the Royal Society of Chemistry, edited by R. 
Massey and D. Taylor, Special Publication No.73, (London: Thomas Graham House), The Royal Society of Chemistry, pp. 52-67.

Dolan, S. P., and Capar, S. G., 2002. Multi-element analysis of food by microwave digestion and inductively coupled plasma-atomic emission spectrometry. Journal of Food Composition and Analysis, 15, 593-615.

Döllken, v., 1898. Ueber die wirkung des aluminiums mit besonderer beriicksichtigung der durch das aluminium verursachten lasionen im centralnervensystem. Archives fur Experimental Pathology and Pharmacology, 40, 98-120.

Ellen, G., Egmond, E., Van Loon, J. W., Sahertian, E. T., and Tolsma, K., 1990. Dietary intakes of some essential and non-essential trace elements, nitrate, nitrite and Nnitrosamines, by Dutch adults: estimated via a 24-hour duplicate portion study. Food Additives and Contaminants, 7, 207-221.

Exley, C. (editor), 2001, Aluminium and Alzheimer's Disease. (New York: Elsevier).

Fairweather-Tait, S. J., Faulks, R. M., Fatemi, S. J. A., and Moore, G. R., 1987. Aluminium in the diet. Human Nutrition: Food Sciences and Nutrition. 41F, 183-192.

Favretto, L. G., 1990. Investigation of trace element content of cheese. Food Additives and Contaminants, 7, 425-432.

Gies, W. J., 1911. Some objections to the use of alum baking-powder. Journal of the American Medical Association, 57, 816-821.

Gormican, A., 1970. Inorganic elements in foods used in hospital menus. Journal of the American Dietetic Association,. 56, 397-403. 
Gramiccioni, L., Ingrao, G., Milana, M. R., Santaroni, P., and Tomassi, G., 1996.

Aluminium levels in Italian diets and in selected foods from aluminium utensils.

Food Additives and Contaminants, 13, 767-74.

Greger, J. L., 1985. Aluminum content of the American diet. Food Technology, 39, 73-

80.

Greger, J. L., and Baier, M. J., 1983. Excretion and retention of low or moderate levels of aluminium by human subjects. Food and Chemical Toxicology, 21, 473-477.

Greger, J. L., Goetz, W., and Sullivan, D., 1985. Aluminum levels in foods cooked and stored in aluminum pans, trays and foil. Journal of Food Protection, 48, 772-777.

Holak, W., 1970. Atomic absorption spectrophotometry of iron and aluminum in baking powders. Journal of the Association of Official Analytical Chemists, 53, 877-879.

Holak, W., 1972. Collaborative study of the determinaton of iron and aluminum in baking powder by atomic absorption spectrophotometry. Journal of the Association of Official Analytical Chemists, 55, 684-685.

Humphreys, S., and Bolger, P. M. 1997. A public health analysis of dietary aluminium. Aluminium Toxicity in Infants' Health and Disease, edited by P. F. Zatta and A. C. Alfrey (Singapore: Singapore World Scientific), pp. 226-237.

Jorhem, L., and Haegglund, G., 1992. Aluminium in foodstuffs and diets in Sweden. Zeitschrift für Lebensmittel-Untersuchung und-Forschung, 194, 38-42.

Lin, J. L., Yang, Y. J., Yang, S. S., and Leu, M. L., 1997. Aluminum utensils contribute to aluminum accumulation in patients with renal disease. American Journal of Kidney Disease, 30, 653-658. 
Lopez, F. E., Cabrera, C., Lorenzo, M. L., and Lopez, M. C., 2002. Aluminum levels in convenience and fast foods: in vitro study of the absorbable fraction. Science of the Total Environment, 300, 69-79.

Müller, M., Anke, M., and Illing-Günther, H., 1998. Aluminium in foodstuffs. Food Chemistry, 61, 419-428.

(NRC) National Research Council (U.S.), Committee on food additives survey data 1984. Poundage update of food chemicals, 1982. (Washington, D.C.: National Academy Press).

Navarro-Blasco, I., and Alvarez-Galindo, J. I., 2003. Aluminium content of Spanish infant formula. Food Additives and Contaminants, 20, 470-481.

Nieboer, E., Gibson, B. L., Oxman, A. D., and Kramer, J. R., 1995. Health effects of aluminum: a critical review with emphasis on aluminum in drinking water. Environmental Reviews, 3, 29-81.

Pennington, J., and Jones, J. 1989. Aluminum in American diets. Aluminum in health, A critical review, edited by H. J. Gitelman), (New York: Marcel Dekker), pp. 67-100.

Pennington, J. A., and Schoen, S. A., 1995. Estimates of dietary exposure to aluminium. Food Additives and Contaminants, 12, 119-128.

Pennington, J. A. T., 1987. Aluminium content of foods and diets. Food Additives and Contaminants, 5, 161-232.

Powell, J. J., and Thompson, R. P., 1993. The chemistry of aluminium in the gastrointestinal lumen and its uptake and absorption. Proceedings of the Nutrition Society, 52, 241-253. 
Priest, N. D., 1993. The bioavailability and metabolism of aluminium compounds in man. Proceedings of the Nutrition Society, 52, 231-240.

Priest, N. D., Talbot, R. J., Newton, D., Day, J. P., King, S. J., and Fifield, L. K., 1998. Uptake by man of aluminium in a public water supply. Human and Experimental Toxicology, 17, 296-301.

Rajwanshi, P., Singh, V., Gupta, M. K., Kumari, V., Shrivastav, R., Ramanamurthy, M., and Dass, S., 1997. Studies on aluminium leaching from cookware in tea and coffee and estimation of aluminium content in toothpaste, baking powder and paan masala. Science of the Total Environment, 193, 243-249.

Rao, G., and Rao, K., 1993. Aluminium content in selected foods. Fresenium Environmental Bulletin, 2, 256-261.

Rogers, M. A. M., and Simon, D. G., 1999. A preliminary study of dietary aluminium intake and risk of Alzheimer's disease. Age and Ageing, 28, 205-209.

Rondeau, V., and Commenges, D. 2001. The epidemiology of aluminium and Alzheimer's disease. Aluminium and Alzheimer's disease, edited by C. Exley, (Amsterdam: Elsevier Science B.V.), pp. 59-73.

Schenk, R. U., Bjorksten, J., and Yeager, L. 1989. Composition and consequences of aluminum in water, beverages and other ingestibles. Environmental Chemistry and Toxicology of Aluminum, edited by T.E. Lewis, (Chelsea, MI.: Lewis Publishers), pp. 247-269.

Sepe, A., Costantini, S., Ciaralli, L., Ciprotti, M., and Giordano, R., 2001. Evaluation of aluminium concentrations in samples of chocolate and beverages by electrothermal atomic absorption spectrometry. Food Additives and Contaminants, 18, 788-796. 
Sherlock, J. C. 1989, Aluminium in foods and the diet. Aluminium in food and the environment; the proceedings of a symposium organised by the environment and Food Chemistry groups of the Industrial Division of the Royal Society of Chemistry, London, 17th May 1988 - (Special publication, no. 73), edited by R. C. Massey and D. Taylor, (Thomas Graham House, London: The Royal Society of Chemistry), pp. $68-75$.

Soni, M. G., White, S. M., Flamm, W. G., and Burdock, G. A., 2001. Safety evaluation of dietary aluminum. Regulatory Toxicology and Pharmacology, 33, 66-79.

Starska, K., 1993. Aluminum in food. Roczniki Panstwowego Zakladu Higieny, 44, 5563.

Stauber, J. L., Florence, T. M., Davies, C. M., Adams, M. S., and Buchanan, S. J., 1999. Bioavailability of $\mathrm{Al}$ in alum-treated drinking water. Journal AWWA (American Water Works Association), 91, 84-93.

Sullivan, D. M., Kehoe, D. F., and Smith, R. L., 1987. Measurement of trace levels of total aluminum in foods by atomic absorption spectrophotometry. Journal of AOAC International, 70, 118-120.

Takeda, Y., Kawamura, Y., and Yamada, T., 1998. Dissolution of aluminium from aluminium foil into foods and effect of food components on the dissolution. Shokuhin Eiseigaku Zasshi (Journal of the Food Hygienic Society of Japan), 39, 266-271.

Taylor, G. A., Ferrier, I. N., McLoughlin, I. J., Fairbairn, A. F., McKeith, I. G., Lett, D., and Edwardson, J. A., 1992. Gastrointestinal absorption of aluminium in Alzheimer's disease: response to aluminium citrate. Age and Ageing, 21, 81-90. 
UK MAFF (United Kingdom Ministry of Agriculture Fisheries and Food), M. 1993, Aluminium in food. The thirty ninth report of the Steering Group on Chemical Aspects of Food Surveillance. Food Surveillance Paper No. 39, (London: HMSO [Her Magesty's Stationery Office]), London. pp. $48+3$ appendices.

Varo, P., Nuurtamo, M., Saari, E., and Koivistoinen, P., 1980a. Mineral element composition of Finnish foods IX. Beverages, confectionaries, sugar and condiments. Acta Agriculturae Scandinavica, Supplementum, 22, 127-139.

Varo, P., Nuurtamo, M., Saari, E., and Koivistoinen, P., 1980b. Mineral element composition of Finnish foods X. Industrial convenience foods, quantity service foods and baby foods. Acta Agriculturae Scandinavica, Supplementum, 22, 141-160.

Vinas, P., Pardo-Martinez, M., and Hernandez-Cordoba, M., 2001. Determination of aluminium and chromium in slurried baby food samples by electrothermal atomic absorption spectrometry. Journal of AOAC International, 84, 1187-1193.

WHO (World Health Organization), International Programme on chemical safety, 1997. Aluminium. Environmental Health Criteria 194 (Geneva: World Health Organization).

Yokel, R. A., and Golub, M. S., (editors). (1997). Research issues in aluminum toxicity. (Washington, D.C.: Taylor \& Francis).

Yokel, R. A., and McNamara, P. J., 2001. Aluminum toxicokinetics: An updated minireview. Pharmacology and Toxicology, 88, 159-167.

Yokel, R. A., and Melograna, J. M., 1983. A safe method to acid digest small samples of biological tissues for graphite furnace atomic absorption analysis of aluminum. Biological Trace Element Research, 5, 225-237. 
Yokel, R. A., Rhineheimer, S. S., Brauer, R. D., Sharma, P., Elmore, D., and McNamara, P. J., 2001. Aluminum bioavailability from drinking water is very low and is not appreciably influenced by stomach contents or water hardness. Toxicology, 161, 93101.

Yokel, R.A., Urbas, A. A., Lodder, R. A., Selegue, J. P., and Florence R. L., 2005. ${ }^{26}$ Alcontaining acidic and basic sodium aluminum phosphate preparation and use in studies of oral aluminum bioavailability from foods utilizing ${ }^{26} \mathrm{Al}$ as an aluminum tracer. Nuclear Instrumentation and Methods in Physics Resesarch. Section B., accepted for publication.

Ysart, G., Miller, P., Croasdale, M., Crews, H., Robb, P., Baxter, M., de L'Argy, C., and Harrison, N., 2000. 1997 UK Total Diet Study--dietary exposures to aluminium, arsenic, cadmium, chromium, copper, lead, mercury, nickel, selenium, tin and zinc. Food Additives and Contaminants, 17, 775-786.

Zook, E. G., and Lehmann, J., 1965. Total diet study: Content of ten minerals aluminum, calcium, phosphorus, sodium, potassium, boron, copper, iron, manganese and magnesium. Journal of the Association of Official Agricultural Chemists. 48, $850-855$. 
table 1. Aluminium in frozen pizza cheese and crust.

\begin{tabular}{|c|c|c|c|c|c|c|}
\hline$\underset{a}{\text { Brand }}$ & $\begin{array}{c}\text { Pizza } \\
\text { type }\end{array}$ & $\begin{array}{c}\text { Al } \\
\text { contributing } \\
\text { ingredient }^{\mathrm{b}}\end{array}$ & $\begin{array}{c}\text { Al } \\
\text { concentration } \\
\left(\mathrm{mg} \mathrm{kg}^{-1}\right)\end{array}$ & $\begin{array}{l}\text { Serving } \\
\text { size }(g)\end{array}$ & $\begin{array}{l}\text { Approximate } \\
\text { weight of the } \\
\text { cheese or } \\
\text { crust in one } \\
\text { serving } \\
\text { (g) }\end{array}$ & $\begin{array}{c}\text { Al / } \\
\text { serving } \\
\text { (mg) }\end{array}$ \\
\hline \multicolumn{7}{|l|}{ Cheese } \\
\hline A01 & $\begin{array}{l}\text { Extra } \\
\text { cheese }\end{array}$ & NA & $2.5 \pm 1.1^{*}$ & 145 & 20.3 & 0.05 \\
\hline $\mathrm{A} 01$ & Pepperoni & SALP & $490 \pm 260^{*}$ & 193 & 12.3 & 6.0 \\
\hline A01 & $\begin{array}{c}\text { Sausage, } \\
\text { pepperoni, } \\
\text { green } \\
\text { peppers \& } \\
\text { onion - } \\
\text { yellow } \\
\text { colour } \\
\text { cheese } \\
\end{array}$ & SALP & $650 \pm 240^{*}$ & 204 & 14.8 & 9.7 \\
\hline A01 & $\begin{array}{c}\text { Sausage, } \\
\text { pepperoni } \\
\text { \& green } \\
\text { peppers \& } \\
\text { onion - } \\
\text { white } \\
\text { colour } \\
\text { cheese }\end{array}$ & SALP & $410 \pm 150$ & 204 & 6.2 & 2.6 \\
\hline A02 & $\begin{array}{l}\text { Italian } \\
\text { cheese }\end{array}$ & NA & $0.54 \pm 0.38$ & 131 & 15.1 & 0.008 \\
\hline A02 & $\begin{array}{c}\text { Italian } \\
\text { sausage } \\
\text { and } \\
\text { pepperoni } \\
\text { pizza } \\
\end{array}$ & SALP & $190 \pm 60$ & 198 & 9.2 & 1.8 \\
\hline A02 & $\begin{array}{l}\text { Sausage, } \\
\text { Canadian } \\
\text { style } \\
\text { bacon and } \\
\text { pepperoni }\end{array}$ & SALP & $590 \pm 270$ & 204 & 9.2 & 5.5 \\
\hline A02 & $\begin{array}{l}\text { Pepperoni, } \\
\text { peppers } \\
\text { and onion }\end{array}$ & SALP & $590 \pm 140^{*}$ & 204 & 12.4 & 7.4 \\
\hline A03 & Cheese & SALP & $320 \pm 150$ & 121 & 21.5 & 6.9 \\
\hline
\end{tabular}




\begin{tabular}{|c|c|c|c|c|c|c|}
\hline A04 & $\begin{array}{c}\text { Original } \\
\text { crisp crust }\end{array}$ & NA & $3.0 \pm 0.5^{*}$ & 139 & 14.7 & 0.044 \\
\hline A04 & $\begin{array}{l}\text { Sliced } \\
\text { pepperoni } \\
\text { - cheese }\end{array}$ & SALP & $480 \pm 180$ & 145 & 16.1 & 7.8 \\
\hline A04 & $\begin{array}{l}\text { Sausage } \\
\text { and } \\
\text { pepperoni }\end{array}$ & SALP & $750 \pm 410$ & 152 & 18.3 & 13.8 \\
\hline A04 & $\begin{array}{c}\text { Sausage \& } \\
\text { pepperoni } \\
\text { with green } \\
\text { peppers \& } \\
\text { onion - } \\
\text { white } \\
\text { colour } \\
\text { cheese }\end{array}$ & SALP & $680 \pm 270^{*}$ & 155 & 3.1 & 2.1 \\
\hline A04 & $\begin{array}{c}\text { Sausage \& } \\
\text { pepperoni } \\
\text { with green } \\
\text { peppers \& } \\
\text { onion - } \\
\text { yellow } \\
\text { colour } \\
\text { cheese }\end{array}$ & SALP & $420 \pm 140^{*}$ & 155 & 6.9 & 2.9 \\
\hline A05 & $\begin{array}{l}\text { Self rising } \\
\text { crust four } \\
\text { cheese }\end{array}$ & NA & $1.7 \pm 0.1^{*}$ & 139 & 16.6 & 0.028 \\
\hline \multicolumn{7}{|l|}{ Crust } \\
\hline A06 & $\begin{array}{l}\text { Cheese } \\
\text { stuffed }\end{array}$ & SALP & $200 \pm 30$ & 120 & 80 & 16 \\
\hline A07 & $\begin{array}{l}\text { Original } \\
\text { crust }\end{array}$ & NA & $12 \pm 9^{*}$ & 140 & 80 & 0.96 \\
\hline
\end{tabular}

${ }^{a}$ Brand codes assigned to maintain anonymity.

${ }^{\mathrm{b}} \mathrm{NA}=$ Aluminium not listed as ingredient

SALP $=$ Sodium aluminium phosphate

${ }^{\mathrm{c}}$ Serving size as stated on the Nutrition Facts label.

*Values based on 4 replicate observations. 
table 2. Aluminium in ready-to-eat restaurant (carry-out, take-away) pizza cheese and crust.

\begin{tabular}{|c|c|c|c|c|}
\hline Brand & Pizza type & $\begin{array}{c}\text { Al } \\
\text { concentration } \\
\left(\mathrm{mg} \mathrm{kg}^{-1}\right)\end{array}$ & $\begin{array}{l}\text { Approximate } \\
\text { weight of } \\
\text { cheese or } \\
\text { crust in a } \\
\text { serving size } \\
\text { (g) a } \\
\end{array}$ & $\begin{array}{c}\text { Al / } \\
\text { serving } \\
\text { (mg) }\end{array}$ \\
\hline \multicolumn{5}{|l|}{ Cheese } \\
\hline B01 & Green pepper & $2.6 \pm 1.6$ & 13.5 & 0.035 \\
\hline B02 & Veggie & $1.8 \pm 0.2$ & 13.5 & 0.024 \\
\hline B03 & Olive & $6.9 \pm 1.7$ & 13.5 & 0.093 \\
\hline B04 & Green pepper & $3.4 \pm 0.7$ & 13.5 & 0.046 \\
\hline B04 & Extra cheese & $3.1 \pm 0.2$ & 13.5 & 0.042 \\
\hline $\begin{array}{c}\text { B05- } \\
2 \text { purchases }\end{array}$ & Cheese & $\begin{array}{l}2.9 \pm 0.4 \\
4.5 \pm 1.9\end{array}$ & 13.5 & 0.050 \\
\hline B06 & $\begin{array}{c}\text { Pepperoni and black } \\
\text { olives }\end{array}$ & $2.5 \pm 0.9$ & 13.5 & 0.034 \\
\hline \multicolumn{5}{|l|}{ Crust } \\
\hline B07 & Cheese & $12 \pm 7^{*}$ & 80 & 1 \\
\hline B08 & Cheese $^{b}$ & $12 \pm 11$ & 80 & 1 \\
\hline
\end{tabular}

${ }^{a}$ Approximate weights are based on the average weights of the cheese and crust in Table $1,13.5$ and $80 \mathrm{~g}$, respectively.

${ }^{\mathrm{b}}$ Pizza purchased in Indiana.

*Value based on 4 replicate observations. 
table 3. Aluminium in cheese

\begin{tabular}{|c|c|c|c|c|c|}
\hline Brand & Product & $\begin{array}{c}\text { Al } \\
\text { contributing } \\
\text { ingredient }^{\mathrm{a}}\end{array}$ & $\begin{array}{c}\text { Al } \\
\text { concentration } \\
\left(\mathrm{mg} \mathrm{kg}^{-1}\right)\end{array}$ & $\begin{array}{c}\text { Weight } \\
\text { of the } \\
\text { cheese } \\
\text { in one } \\
\text { serving } \\
\text { (g) } \\
\end{array}$ & $\begin{array}{c}\mathrm{Al} / \\
\text { serving } \\
\text { (mg) }\end{array}$ \\
\hline $\mathrm{C} 01$ & $\begin{array}{c}\text { Cheddar cheese, } \\
\text { sharp }\end{array}$ & NA & $3.9 \pm 3.9$ & 28.4 & 0.11 \\
\hline $\mathrm{C} 02$ & $\begin{array}{c}\text { Processed } \\
\text { American cheese } \\
\text { slices }\end{array}$ & SALP & $470 \pm 200^{*}$ & 19 & 8.9 \\
\hline $\mathrm{C} 03$ & $\begin{array}{c}\text { Processed } \\
\text { American cheese } \\
\text { slices }\end{array}$ & SALP & $14 \pm 6^{*}$ & 19 & 0.27 \\
\hline C04 & $\begin{array}{c}\text { American } \\
\text { pasteurized } \\
\text { prepared cheese }\end{array}$ & NA & $6.6 \pm 4.4^{*}$ & 19 & 0.13 \\
\hline $\mathrm{C} 05$ & $\begin{array}{c}\text { Processed } \\
\text { American cheese } \\
\text { slices }\end{array}$ & NA & $40 \pm 55^{*}$ & 19 & 0.76 \\
\hline
\end{tabular}

${ }^{\mathrm{a}} \mathrm{NA}=$ Aluminium not listed as ingredient

SALP = Sodium aluminium phosphate

${ }^{*}$ Values based on 4 replicate observations. 
table 4. Aluminium in baking supplies, baked goods, pancakes and waffles.

\begin{tabular}{|c|c|c|c|c|c|}
\hline Brand & Product & $\begin{array}{c}\text { Al } \\
\text { contributing } \\
\text { ingredient }^{\mathrm{a}}\end{array}$ & $\begin{array}{c}\mathrm{Al} \\
\text { concentration } \\
\left(\mathrm{mg} \mathrm{kg}^{-1}\right)\end{array}$ & $\begin{array}{l}\text { Serving } \\
\text { Size } \\
\text { (g) }\end{array}$ & $\begin{array}{c}\text { Al/ } \\
\text { serving } \\
(\mathbf{m g})\end{array}$ \\
\hline D01 & $\begin{array}{l}\text { All-purpose enriched } \\
\text { bleached pre-sifted } \\
\text { flour }\end{array}$ & NA & $19 \pm 10$ & 30 & 0.57 \\
\hline D02 & Baking mix original & NA & $830 \pm 480$ & 40 & 33 \\
\hline D03 & Baking (biscuit) mix & NA & $20 \pm 5$ & 32 & 0.64 \\
\hline D04 & $\begin{array}{l}\text { White corn meal mix } \\
\text { self rising }\end{array}$ & NA & $170 \pm 120$ & 34 & 5.6 \\
\hline D05 & $\begin{array}{l}\text { Self-rising white corn } \\
\text { meal mix }\end{array}$ & NA & $25 \pm 10$ & 25 & 0.62 \\
\hline D06 & Baking powder & SALP & $18000 \pm 9000$ & 0.6 & 11 \\
\hline D07 & Baking powder & SALP & $28000 \pm 1000$ & 1.1 & 30 \\
\hline D08 & Carrot cake mix & SALP & $440 \pm 60$ & 51 & 22 \\
\hline D09 & Golden cake mix & NA & $20 \pm 2$ & 52.4 & 1.2 \\
\hline D10 & Angel food cake mix & NA & $2 \pm 2$ & 37.8 & 0.09 \\
\hline D11 & White cake mix & SALP & $820 \pm 150$ & 43 & 35 \\
\hline $\mathrm{D} 12$ & Pancake, waffle mix & SALP & $1200 \pm 600^{*}$ & 47 & 57 \\
\hline D13 & Pancake, biscuit mix & NA & $1080 \pm 210$ & 40 & 43 \\
\hline D14 & Complete pancake mix & NA & $670 \pm 100$ & 47 & 31 \\
\hline D15 & $\begin{array}{c}\text { Whole wheat } \\
\text { buttermilk pancake } \\
\text { mix }\end{array}$ & NA & $19 \pm 1$ & 40 & 0.77 \\
\hline
\end{tabular}




\begin{tabular}{|c|c|c|c|c|c|}
\hline D16 & Pancake mix & SALP & $620 \pm 460$ & 43 & 27 \\
\hline D17 & $\begin{array}{l}\text { Buttermilk pancake } \\
\text { mix }\end{array}$ & NA & $70 \pm 55$ & 43 & 2.9 \\
\hline D17 & $\begin{array}{l}\text { Blueberry muffin mix } \\
\text { bakery style }\end{array}$ & SALP & $470 \pm 210$ & 56 & 26 \\
\hline D18 & Blueberry muffin mix & SALP & $490 \pm 30$ & 36 & 18 \\
\hline D19 & $\begin{array}{l}\text { Chocolate chip cookie } \\
\text { refrigerated dough }\end{array}$ & NA & $8 \pm 5$ & 25.5 & 0.22 \\
\hline D20 & $\begin{array}{c}\text { Chocolate chunk } \\
\text { cookies refrigerated } \\
\text { dough }\end{array}$ & NA & $90 \pm 61$ & 25.5 & 2.3 \\
\hline D21 & $\begin{array}{l}\text { Buttermilk biscuits } \\
\text { refrigerated dough }\end{array}$ & NA & $30 \pm 8$ & 63.5 & 2 \\
\hline D22 & $\begin{array}{l}\text { Buttermilk scratch } \\
\text { biscuits refrigerated } \\
\text { dough }\end{array}$ & NA & $98 \pm 51$ & 31 & 3 \\
\hline D23 & $\begin{array}{c}\text { Frozen Cinnamon } \\
\text { Rolls }\end{array}$ & SALP & $390 \pm 220$ & 44 & 17 \\
\hline D24 & $\begin{array}{c}\text { Frozen Cinnamon } \\
\text { Rolls }\end{array}$ & NA & $45 \pm 18$ & 44 & 2.1 \\
\hline D25 & $\begin{array}{l}\text { Frozen pre-baked } \\
\text { waffle, buttermilk }\end{array}$ & NA & $11 \pm 8^{*}$ & 69.6 & 0.79 \\
\hline $\mathrm{D} 26$ & $\begin{array}{l}\text { Frozen buttermilk } \\
\text { waffle }\end{array}$ & NA & $600 \pm 120$ & 69.8 & 41 \\
\hline D27 & $\begin{array}{l}\text { Frozen buttermilk } \\
\text { pancake }\end{array}$ & NA & $300 \pm 25$ & 116 & 35 \\
\hline $\mathrm{D} 28$ & Frozen raspberry pie & NA & $3 \pm 4$ & 131 & 0.39 \\
\hline D29 & Restaurant pancake ${ }^{b}$ & NA & $1200 \pm 590$ & 141 & 165 \\
\hline D30 & Restaurant pancake ${ }^{\mathrm{c}}$ & NA & $880 \pm 100$ & $\begin{array}{c}141 \\
\text { (based } \\
\text { on D29) }\end{array}$ & 124 \\
\hline D31 & Restaurant pancake & NA & $450 \pm 130$ & 210 & 95 \\
\hline
\end{tabular}




\begin{tabular}{|c|c|c|c|c|c|}
\hline D32 & Restaurant pancake & NA & $530 \pm 80$ & 270 & 142 \\
\hline D33 & Restaurant pancake & NA & $560 \pm 130$ & 324 & 182 \\
\hline D34 & Restaurant pancake & NA & $430 \pm 50$ & 120 & 52 \\
\hline D35 & Restaurant waffle & NA & $43 \pm 14$ & 140 & 6 \\
\hline D36 & Doughnut & NA & $9 \pm 6$ & 60 & 0.6 \\
\hline D36 & $\begin{array}{c}\text { Raspberry filled } \\
\text { doughnut }\end{array}$ & NA & $7 \pm 4$ & 60 & 0.4 \\
\hline D36 & Glazed cruller & NA & $21 \pm 7$ & 60 & 1.3 \\
\hline
\end{tabular}

${ }^{a} \mathrm{NA}=$ Aluminium not listed as ingredient SALP $=$ Sodium aluminium phosphate

${ }^{\mathrm{b}}$ Product purchased in Canada

${ }^{c}$ Product purchased in Utah.

${ }^{*}$ Values based on 4 replicate observations. 
table 5. Aluminium in non-dairy creamer powder and cocoa

\begin{tabular}{|c|c|c|c|c|c|}
\hline Brand & Type & $\begin{array}{c}\text { Al } \\
\text { contributing } \\
\text { ingredient }^{\mathrm{a}}\end{array}$ & $\begin{array}{c}\text { Al } \\
\text { concentration } \\
\left(\mathrm{mg} \mathrm{kg}^{-1}\right)\end{array}$ & $\begin{array}{l}\text { Serving } \\
\text { Size } \\
\text { (g) }\end{array}$ & $\begin{array}{c}\mathrm{Al} / \text { serving } \\
\text { (mg) }\end{array}$ \\
\hline \multicolumn{6}{|c|}{ Single-serving non-dairy creamer packet } \\
\hline E01 & & SAS & $160 \pm 60$ & 2.7 & 0.44 \\
\hline E02 & & SAS & $250 \pm 100$ & 2.7 & 0.68 \\
\hline E03 & & SAS & $110 \pm 40$ & 2.4 & 0.26 \\
\hline E04 & & SAS & $110 \pm 50$ & 2.4 & 0.26 \\
\hline E05 & & SAS & $255 \pm 40$ & 2.1 & 0.54 \\
\hline E06 & & SAS & $590 \pm 140$ & 2.5 & 1.5 \\
\hline E07 & & SAS & $180 \pm 40$ & 2.5 & 0.45 \\
\hline \multicolumn{6}{|c|}{ Multiple-serving non-dairy creamer container } \\
\hline E08 & $\begin{array}{l}\text { Creamer } \\
\text { original }\end{array}$ & NA & $7 \pm 4$ & 2 & 0.10 \\
\hline E09 & Hazelnut flavour & SAS & $50 \pm 11$ & 12 & 0.60 \\
\hline \multicolumn{6}{|c|}{ Cocoa and milk chocolate mixes } \\
\hline E10 & Hot cocoa mix & SAS & $150 \pm 80$ & 20 & 3 \\
\hline E11 & $\begin{array}{l}\text { Hot cocoa mix } \\
\text { with mini } \\
\text { marshmallows }\end{array}$ & NA & $25 \pm 8$ & 28.3 & 0.67 \\
\hline E12 & $\begin{array}{l}\text { Hot cocoa mix } \\
\text { with milk } \\
\text { chocolate } \\
\text { marshmallows }\end{array}$ & NA & $6 \pm 4$ & 28.3 & 0.18 \\
\hline
\end{tabular}

${ }^{\mathrm{a}} \mathrm{NA}=$ Aluminium not listed as ingredient

SAS $=$ Sodium aluminosilicate 
table 6. Aluminium in salt

\begin{tabular}{|c|c|c|c|c|}
\hline Brand $^{a}$ & $\begin{array}{l}\text { Al contributing } \\
\text { ingredient }^{b}\end{array}$ & $\begin{array}{l}\text { Al concentration } \\
\left(\mathrm{mg} \mathrm{kg}^{-1}\right)\end{array}$ & $\begin{array}{c}\text { Approximate } \\
\text { total packet or } \\
\text { serving weight (g) }\end{array}$ & $\begin{array}{c}\text { Al / } \\
\text { serving } \\
\text { (mg) }\end{array}$ \\
\hline \multicolumn{5}{|c|}{ Single-serving Packet } \\
\hline F01 & SAS & $190 \pm 20$ & 0.75 & 0.14 \\
\hline F02 & SAS & $180 \pm 40^{*}$ & 0.75 & 0.13 \\
\hline F03 & SAS & $150 \pm 45$ & 1.5 & 0.22 \\
\hline F04 & SAS & $195 \pm 28^{*}$ & 0.5 & 0.098 \\
\hline F05 & NA & $170 \pm 45^{*}$ & 0.5 & 0.085 \\
\hline F06 & NA & $3 \pm 2$ & 0.5 & 0.0015 \\
\hline \multicolumn{5}{|c|}{ Multiple-serving container } \\
\hline F07 & SAS & $125 \pm 30$ & 1.5 & 0.19 \\
\hline F08 & NA & $3 \pm 1$ & 1.5 & 0.0045 \\
\hline
\end{tabular}

${ }^{\mathrm{a}} \mathrm{F} 01, \mathrm{~F} 02, \mathrm{~F} 03, \mathrm{~F} 05, \mathrm{~F} 07, \mathrm{~F} 08$ made in USA, F04 and F06 made in Canada.

${ }^{\mathrm{b}} \mathrm{NA}=$ Aluminium not listed as ingredient

$\mathrm{SAS}=$ Sodium aluminosilicate

*Values based on 4 replicate observations. 
table 7. Aluminium in pickle relish

\begin{tabular}{|c|c|c|c|c|c|}
\hline Brand & Product & $\begin{array}{c}\text { Al } \\
\text { contributing } \\
\text { ingredient }^{\text {a }}\end{array}$ & $\begin{array}{c}\text { Al concentration } \\
\text { (mg kg }^{-1} \text { ) }\end{array}$ & $\begin{array}{c}\text { Serving } \\
\text { Size } \\
(\mathbf{g})\end{array}$ & $\begin{array}{c}\text { Al / } \\
\text { serving } \\
\text { (mg) }\end{array}$ \\
\hline G01 & Sweet relish & Alum $^{\text {b }}$ & $40 \pm 5$ & 15 & 0.6 \\
\hline G02 & Sweet relish & NA & $11 \pm 1$ & 15 & 0.2 \\
\hline G03 & Dill relish & Alum & $73 \pm 40$ & 15 & 1.1 \\
\hline
\end{tabular}

${ }^{\mathrm{a}} \mathrm{NA}=$ Aluminium not listed as ingredient

${ }^{\mathrm{b}}$ Alum $=\mathrm{Al}$ potassium sulfate 
table 8. Quality control samples

\begin{tabular}{|c|c|c|c|c|}
\hline Brand & $\begin{array}{l}\text { Food Product } \\
\text { (Matrix) }\end{array}$ & $\begin{array}{l}\text { Form of Al } \\
\text { added }\end{array}$ & $\begin{array}{c}\text { Target Al } \\
\text { Concentration } \\
\left(\mathrm{mg} \mathrm{kg}^{-1}\right)\end{array}$ & $\begin{array}{l}\text { Determined Al } \\
\text { concentration } \\
\left(\mathrm{mg} \mathrm{kg}^{-1}\right)^{\mathrm{a}} \\
\end{array}$ \\
\hline $\mathrm{C} 01$ & $\begin{array}{l}\text { Classic sharp } \\
\text { cheddar cheese }\end{array}$ & Kasal® & 820 & $780 \pm 20$ \\
\hline E08 & $\begin{array}{l}\text { Non-dairy } \\
\text { creamer }\end{array}$ & $\mathrm{AlK}_{2} \mathrm{SO}_{4}$ & 305 & $300 \pm 30$ \\
\hline F08 & Salt & $\mathrm{AlK}_{2} \mathrm{SO}_{4}$ & 260 & $320 \pm 20$ \\
\hline D02 & Baking mix & $\mathrm{AlK}_{2} \mathrm{SO}_{4}$ & 22000 & $21000 \pm 400$ \\
\hline D10 & Cake mix & $\mathrm{AlK}_{2} \mathrm{SO}_{4}$ & 525 & $450 \pm 40$ \\
\hline D25 & $\begin{array}{l}\text { Pre-baked } \\
\text { waffle, } \\
\text { buttermilk }\end{array}$ & $\mathrm{AlK}_{2} \mathrm{SO}_{4}$ & 580 & $570 \pm 50$ \\
\hline G02 & Sweet relish & $\begin{array}{c}\text { Atomic } \\
\text { absorption } \\
\text { standard } \\
\text { solution } \\
\text { (Aldrich) } \\
\end{array}$ & 50 & $48 \pm 4$ \\
\hline
\end{tabular}

${ }^{a}$ Results from five aliquots analyzed independently. 